JURNAL ILMIAH TEKNOLOGI INFORMASI DAN KOMUNIKASI (JTIK) VOL 12, No.2, September 2021,

pp. $69-73$

p-ISSN : $2087-0868$ (media cetak)

e-ISSN : 2598-9707 (media online)

http://ejurnal.provisi.ac.id/index.php/JTIKP

\title{
VIDEO ANIMASI 3D HIDUP DIERA NEW NORMAL $3 \mathrm{~d}$ animation videos live in the new normal era
}

\author{
Kurnia Handara ${ }^{1}$ \\ ${ }^{1}$ Fakultas Ilmu Komputer, Univeritas Amikom Purwokerto \\ ${ }^{1}$ kuniahandara@gmail.com
}

\section{ARTICLE INFO}

Article history:

Received : 28 - Agustus - 2021

Received in revised form : 7 - September - 2021

Accepted : 11 - Oktober - 2021

Available online : 16 - Oktober - 2021

\begin{abstract}
The purpose of this research is to create a 3dimensional animated video of life in the new normal era to increase public understanding of the new normal. Data collection methods used in this study include observation, interviews, documentation, and questionnaires. The result of this research is a live 3-dimensional animation video in the new normal era with a duration of 3 minutes 17 seconds in .mp4 format.
\end{abstract}

Keywords : Animation, Blender, New Normal.

\begin{abstract}
Abstrak
Tujuan penelitian ini adalah membuat video animasi 3 dimensi hidup diera new normal untuk meningkatkan pemahaman masyarakat mengenai new normal. Metode pengumpulan data yang digunakan dalam penelitian ini meliputi metode obsevasi, wawancara, dokumentasi, dan kuesioner. Hasil dari penelitian ini berupa video animasi 3 dimensi hidup diera new normal berdurasi 3 menit 17 detik dengan format .mp4.
\end{abstract}

Kata Kunci : Animasi, Blender, New Normal

\section{PENDAHULUAN}

New normal adalah perubahan sosial masyarakat di masa pandemi Covid-19 [1]. Pada tahap ini, manusia membatasi ontak fisik orang lain. Kegiatan masyarakat berubah membuat dunia bisnis menurun, seperti pariwisata, perekonomian, trasnportasi dan lainnya [2]. Seiring bertambahnya waktu, tinggal di rumah tidak terus menerus diterapkan. Virus SARS-CoV-2 yang mengakibatkan Covid-19 semakin mengancam. Korban jiwa akibat Covid19 terus meningkat. Dan disinilah, adaptasi kebiasanan baru atau new normal diterapkan [3].

Untuk mencegah penyebaran Covid-19 secara meluas, pemerintah menghimbau masyarakat tinggal di rumah, sekolah bahkan bekerja pun di rumah. Pada tahap ini harus memperhatikan segala protokol kesehatan yang ditetapkan oleh Organisasi Kesehatan Dunia (WHO) [4].

Pemerintah dan para medis terus mengambil langkah-langkah untuk mencegah penyebaran Covid-19. Salah satu yang dilakukan adalah berupa social distancing, isolasi mandiri dan beradaptasi dengan kebiasaan baru [5]. Masyarakat Indonesia harus menerapkan prosedur kebersihan untuk mencegah penyebaran Covid-19.

Covid-19 telah memberikan dampak besar pada perekonomian negara. Sistem ekonomi Indonesia adalah sistem ekonomi kerakyatan, dan perekonomian dikuasai oleh rakyat. Namun, kegiatan ekonomi saat ini pada kenyataannya mencerminkan sistem ekonomi kapitalis, dan dapat dikatakan terjadi dualisme ekonomi. Kegiatan masyarakat sudah dimulai, namun tetap memperhatikan pedoman pola hidup sehat. Berbagai kegiatan sosialisasi harus dilakukan, seperti sosialisasi kepada masyarakat untuk melaksanakan kesepakatan agar dapat memutus rantai penyebaran Covid-19 [6].

Dinas Kesehatan adalah lembaga yang dibentuk untuk melaksanakan tugas dan fungsi dalam bidang kesehatan. Berdasarkan hasil wawancara yang dilakukan dengan Bapak Anton Ari Wibowo Ketua Promosi Kesehatan dan Pemberdayaan Masyarakat di Dinas Kesehatan Kabupaten Banyumas, didapatkan informasi bahwa Kabupaten 
Banyumas merupakan kasus Covid-19 tertinggi daripada Kabupaten tetangga seperti Kabupaten Tegal, Kabupaten Purbalingga, Kabupaten Cilacap, dan Kabupaten Brebes. Dan media sosialisasi yang digunakan oleh pihak Dinas Kesehatan Kabupaten Banyumas masih secara lisan yaitu berdialog langsung dan menggunakan media presentasi berupa power point dan poster. Beliau berpendapat sosialisasi menggunakan media tersebut kurang efektif karena membutuhkan banyak waktu dalam penyampaian informasi terlebih pada masa pandemi seperti ini. Menurut beliau harus ada media lebih efektif untuk mensosialsasikan seperti video agar masyarakat beran-benar memahami informasi yang disampaikan. Sehingga penulis mengusulkan kegiatan sosialisasi menggunakan video animasi $3 \mathrm{~d}$.

\section{TINJAUAN PUSTAKA}

a. Multimedia

Secara etimologi kata "media" merupakan bentuk jamak dari "medium", yang berarti berasal dan Bahasa Latin "medius" berarti tengah. Dalam Bahasa Indonesia, kata "medium" diartikan sebagai "antara" atau "sedang". Jadi pengertian multimedia diartikan sebagai mengarah pada suatu informasi kemudian meneruskan informasi (pesan) antara pemberi kepada penerima pesan [7].

b. Video

Kata video berasal dari singkatan Bahasa Inggris "visual (Vi)" berarti "gambar" dan "audio (deo)" berarti suara. Sehingga video merupakan komponen media yang menyajikan gambar dan suara dalam waktu bersama. Pada dasarnya video mengubah gagasan menjadi sebuah tampilan gambar dan suara yang menarik [8].

c. Animasi

Animasi bagian cabang sinematografi, sebuah animasi tidak dapat dipisahkan dari dari film. Seperti cut, sequence, frame, continuity, sudut pandang (angle), tansisi gambar, skenario, dan sebagainya [8].

d. New Normal

New Normal menggambarkan kehidupan sosial dalam masyarakat selama Covid-19. New normal menjelaskan berubahnya keadaan akibat lamanya kehidupan masyarakat selama Covid-19. Oleh karena itu, kehidupan masyarakat tidak bisa lepas dari kemungkinan sosialisasi dengan normal baru [2].

\section{METODOLOGI PENELITIAN}

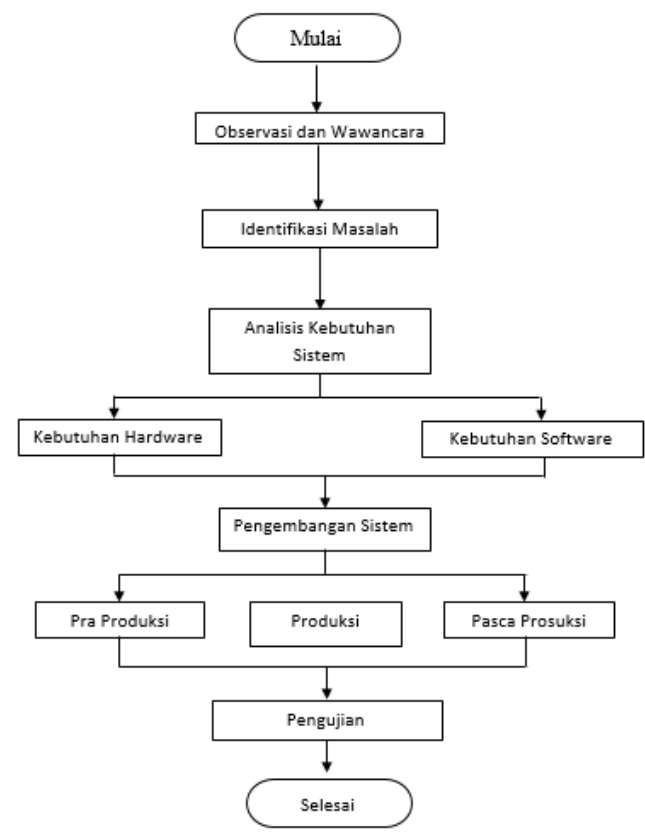

Metode penelitian ini adalah :

Gambar 1. Metode Penelitian

a. Obsevasi

VIDEO ANIMASI 3D HIDUP DIERA NEW NORMAL 3d animation videos live in the new normal era Kurnia Handara ${ }^{1}$ 
Observasi merupakan metode pengumpulan data meliputi berbagai proses biologis dan psikologis [9]. Dari hasil observasi penulis mendapatkan permasalahan tentang new normal bahwa pedagang disepanjang jalan yang tidak menerapkan protokol kesehatan menimbulkan peningkatan penyebaran Covid-19, bergerombolnya tempat umum tanpa mengindahkan protokol kesehatan.

b. Wawancara

Wawancara merupakan metode pengumpulan information yang memberi pertanyaan kepada narasumber untuk mendapatkan informasi mengenai yang akan diteliti [9], Dalam penelitian ini penulis mewawancarai petugas promosi kesehatan dan berberdayaan masyarakat dari Dinas Kesehatan Kabupaten Banyumas untuk medapatkan informasi mengenai new normal.

c. Identifikasi Masalah

Mengidentifikasi masalah yang terdapat dalam masyarakat, kemudian observasi yaitu mendatangi suatu tempat atau sumber terkait masalah tersebut untuk mencari data atau sumber yang dapat dijadikan informasi tambahan [10].

d. Analisis Kebutuhan Sistem

Analisis kebutuhan sistem dalam penelitian ini yaitu kebutuhan hardware / perangkat keras : Processor Intel Core i3-7020U. 2.3 GHz, RAM : 4 GB, Harddsik : 1TB, dan 1 unit mouse. Software / perangkat lunak : Sistem Operasi Windows 10 64-bit, Blender 3D 2.90.1, Adobe Premier Pro 2019, dan Adobe Audition CC 2018.

e. Metode Pengembangan Sistem

Menggunakan Metode pengembanga [9]. Dalam metode pengembangan sistem tersebut terdapat tiga tahapan yaitu : Pra-Produksi, Produksi, dan Paska-Produksi.

f. Kuesioner

merupakan Metode pengumpulan informasi yang diisi dengan memberi pertanyaan atau pernyataan ditunjukan kepada responden. [7].

\section{HASIL DAN PEMBAHASAN}

Video animasi 3D dapat ditayangkan melalui media video flashdisk dimana masyarakat dapat melihat video animasi ini dengan mudah. Untuk tahapannya akan dijelaskan sebagai berikut.

1) Tahap Pra Produksi

Tahapan berikut adalah pembuatan secara keseluruhan untuk dipesiapkan sebagai penciptaan animasi video meliputi ide cerita, tema cerita, skenario, sketsa, storyboard, dan take voice.

2) Tahap Produksi

Merupakan tahap dimana pembuatan video animasi 3d hidup diera new normal dibuat. Berikut merupakan tahapan dalam proses produksi yang dilalukan adalah sebagai berikut:

a. Modelling

Pada proses ini objek dan enviroment. Softwareini digunakan karena membuat modellingmenjadi lebih mudah dan hasil animasi yang dibuat menjadi cukup bagus. Modeling Karakter Pada gambar 4.2 dibawah adalah hasil pembentukan karakter yang di awali pembuatan menggunakan plane.

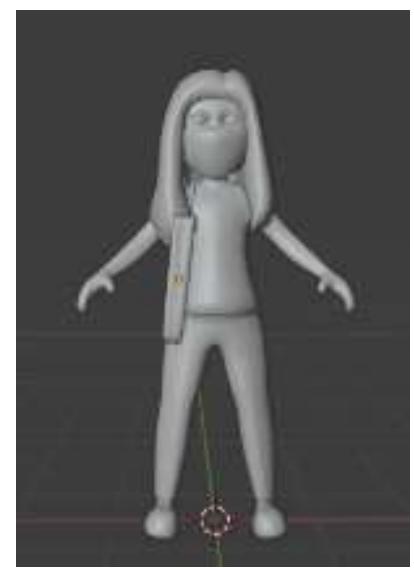

JURNAL ILMIAH TEKNOLOGI INFORMASI DAN KOMUNIKASI (JTIK) VOL 12, No.2, September 2021, pp. 59 $-73$ 
b. Texturing

Gambar 2. Model Karakter

Pada tahap ini pemberian warna dengan material agar tampak hidup. Menggunakan texturing pada software Blender 3D.

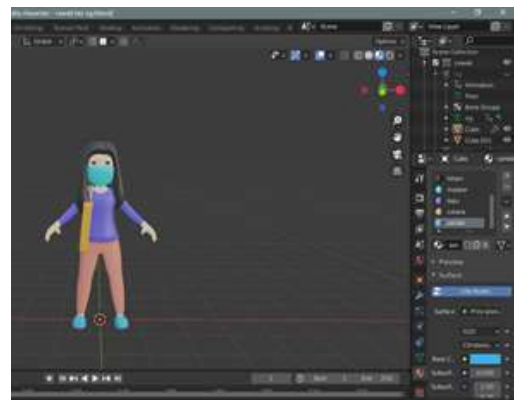

Gambar 3. Texturing karakter

c. Rigging

Pada langkah ini merupakan proses dimana objek 3 dimensi dilakukan penambahan tulang atau riggingkarakter sehingga objek 3 dimensi yang telah dibuat dapatdilakukan proses animasi.

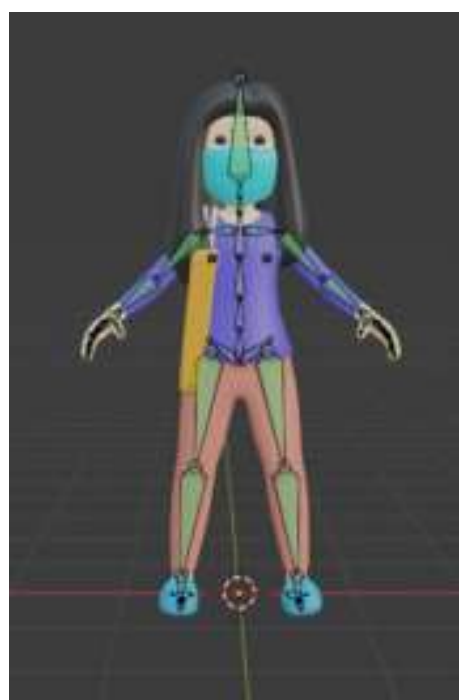

Gambar 4. Proses Ringing

d. Lighting

Penulis menggunakan pengaturan World Scene dengan High Dynamic Range (HDR) terdapat pada menu world properties untuk mengatur pencahayaan dan mendapatkan hasil rendering yang baik serta lebih realistis.

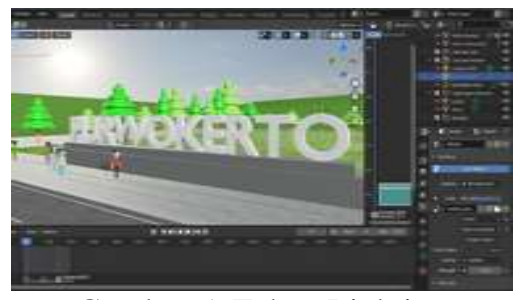

Gambar 5. Tahap Lighting

VIDEO ANIMASI 3D HIDUP DIERA NEW NORMAL 3d animation videos live in the new normal era Kurnia Handara ${ }^{1}$ 
e. Animasi

Model sudah diberi tulang atau rigging untuk memudahkan dalam penganimasian agar bergerak.

Pergerakan animasi menggunakan keyframe untuk memudahkan perubahan dari gerakan satu kegerakan lainnya.

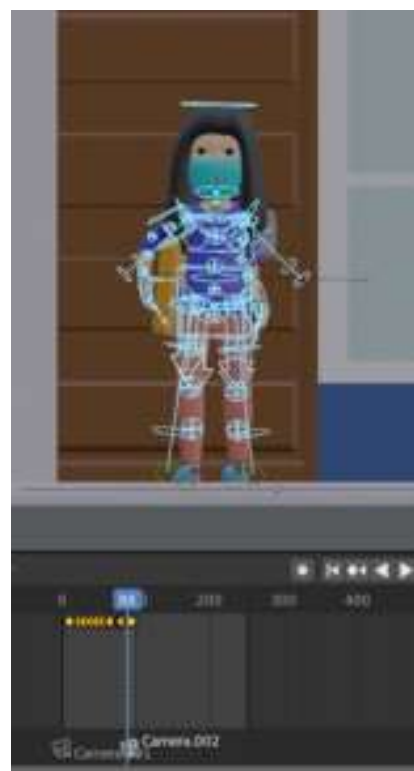

Gambar 6. Tahap Animasi

f. Redering

Penulis menggunakan format FFmpeg video output file MPEG-4. Tahapan ini dapat membuat tampilan bagus dari akhir penciptaan animasi 3D.

3) Tahap Pasca Produksi

Merupakan tahap akhir menyatukan yang sudah dikerjakan dalam proses produksi "Video Animasi 3D Hidup Diera New Normal" Berikut merupakan tahapan dalam proses pasca produksi meliputi compositing, Adding Sound and Audio, Final Rendering.

\section{PENGUJIAN}

Pengujian dilakukan oleh 101 responden dan kemudian responden ini akan menentukan persentase pemahaman masyarakat mengenai new normal. Penilaian tanggapan dari responden menggunakan skala likert. Skala likert ini memiliki 5 aspek dan memiliki bobot nilai tersendiri [10].

\section{KESIMPULAN DAN SARAN}

Video animasi 3d hidup diera new normal telah penulis buat yang bertujuan untuk meningkatkan pemahaman masyarakat mengenai new normal dan hal yang harus dilakukan ketika berada diluar rumah guna memutus penyebaran Covid-19. Seperti selalu memkai masker, selalu mencuci tangan atau membawa handsanitizer, dan berjaga jarak.

Pengujian melalui kuesioner terhadap 101 responden dan menghasikan nilai 85,6\% dengan kategori sangat setuju, sehingga video animasi $3 \mathrm{~d}$ ini dapat meningkatkan pemahaman masyarakat Kabupaten Banyumas mengenai new normal. Saran untuk penelitian selanjutnya dapat menambahkan cara mencuci tangan yang benar. Penulis harap pada penelitian selanjutnya menambah cara mencuci tangan yang benar agar sesuai dengan protokol kesehatan new normal.

\section{DAFTAR PUSTAKA}

[1] Susilo, A. (2020). Corona disease 2019: Tinjauan literatur terkini. Jurnal Penyakit Dalam Indonesia, JURNAL ILMIAH TEKNOLOGI INFORMASI DAN KOMUNIKASI (JTIK) VOL 12, No.2, September 2021, pp. 59 $-73$ 
$7(3), 45-67$.

[2] Habibi, A. (2020). Normal baru pasca Covid-19. Jurnal Kultur, 4(1), 197-204.

[3] Bramasta, D. B. (2020). Mengenal apa itu new normal di tengah pendemi corona. Diambil dari. https:/www.kompas.com/tren/read/2020/05/20/063100865/mengenal-apa-itu-new-normal-di-tengahpandemi-corona-?page=all, diakses pada 12 Juli 2021.

[4] Griffith, K. (2020). The new normal after coronavirus. Diambil dari https://www.ksn.com/news/capitolbureau/the-new-normal-after-coronavirus/, diakses pada 12 Juli 2021

[5] Buana, D. R. (2020). Analisis perilaku masyarakat Indonesia dalam menghadapi pandemi Virus Corona (Covid-19) dan kiat menjaga kesejahteraan jiwa. Jurnal Sosial Budaya, 7(3), 217-226.

[6] Yunus, N. R. (2020). Kebijakan pemberlakuan lock down sebagai antisipasi penyebaran corona virus Covid-19. Jurnal Sosial Budaya, 7(3), 227-238.

[7] Ninghardjanti, P. (2020). Buku berbasis riset: pembelajaran multimedia berbasis mobile learning. Banyumas: Pena Persada.

[8] P. Soenyoto, Animasi 2D. Jakarta: Elex Media Komputindo, 2017.

[9] Sugiyono, (2018). Metode penelitian bisnis (pendekatan kuantitatif, kualitatif, kombinasi, dan R\&D). Bandung: Alfabeta.

[10] A. Febrian and T. Astuti, "VIDEO ANIMASI 3D SEBAGAI MEDIA PENYULUHAN PENYAKIT TIFUS DI,” pp. 304-309, 2018. 